\title{
Effects of Multiple Supplementary Cementitious Materials on Workability and Segregation Resistance of Lightweight Aggregate Concrete
}

\author{
Afonso Miguel Solak ${ }^{1}$, Antonio José Tenza-Abril ${ }^{1, * \mathbb{C}}$, José Miguel Saval ${ }^{1}$ and \\ Victoria Eugenia García-Vera ${ }^{2}$ \\ 1 Department of Civil Engineering, University of Alicante, 03080 Alicante, Spain; ams164@alu.ua.es (A.M.S.); \\ jm.saval@ua.es (J.M.S.) \\ 2 Departamento de Arquitectura y Tecnología de la Edificación, Universidad Politécnica de Cartagena, \\ 30203 Murcia, Spain; victoria.eugenia@upct.es \\ * Correspondence: ajt.abril@ua.es; Tel.: +34-96-5903-400 (ext. 2729)
}

Received: 30 October 2018; Accepted: 16 November 2018; Published: 20 November 2018

\begin{abstract}
In view of the global sustainable development, it is imperative that supplementary cementing materials (SCM) be used for replacing cement in the concrete industry and several researchers have shown that mineral admixtures can enhance the workability of lightweight aggregate concrete (LWAC) mixture and its strength. In view of the beneficial effects of using SCM in LWAC, this article aims to verify the possible influence of the use of different types of SCM in the segregation phenomenon of LWAC. Three different SCM were studied: Silica Fume (SF), Fly Ash (FA) and Posidonia oceanica Ash (PA). For each SCM, three mixtures were prepared, considering three different percentage substitutions of cement. An image analysis technique was applied to estimate the segregation in each sample. The results show that a substitution of cement by other materials with different grain size, considering a constant water binder ratio, may also result in a variation of the consistency of concrete and the viscosity of the mortar matrix, which may contribute to increase or reduce segregation.
\end{abstract}

Keywords: supplementary cementitious materials; silica fume; fly ash; Posidonia oceanica ash; segregation; lightweight aggregate concrete (LWAC); compaction; vibration

\section{Introduction}

During the last few years, EU member states have been publishing and adopting Energy Performance Building Directives looking for improvements of the energy performance of the European buildings and thus looking for solutions to satisfy the growing comfort needs and increases in energy consumption destined to heat, ventilation, and air-conditioning (HVAC) systems [1,2]. The energy needs and the thermal bridging effects could be reduced if alternative materials with better thermal properties were employed as an alternative to normal weight concrete, as is the case of the structural lightweight aggregate concrete (LWAC) [3].

LWACs, as consequence of the replacement of part of their solid materials by air, are characterized by having lower values of specific weight when compared with conventional concretes. In these materials, aggregates of reduced specific weight are used-with bulk densities significantly lower than $2600 \mathrm{~kg} / \mathrm{m}^{3}$ - for replacing the normal-weight aggregates. These materials, natural or artificial aggregates, can reach bulk densities below $300 \mathrm{~kg} / \mathrm{m}^{3}$ [4]. Eurocode 2 [5] defines that a structural LWAC should have a bulk density of not more than $2200 \mathrm{~kg} / \mathrm{m}^{3}$, whereas the ACI 213R-03 [6] establishes the maximum limit of $1920 \mathrm{~kg} / \mathrm{m}^{3}$. 
In view of global sustainable development, it is imperative that supplementary cementing materials (SCM) be used for replacing cement in the concrete industry [7] and several researchers have shown that mineral admixtures can enhance the workability of LWAC mixture and its strength [8]. The use of industrial by-products, mostly siliceous and aluminous materials like fly ash [9], silica fume, slags, and natural pozzolanic materials like volcanic tuffs and diatomaceous earth may be used as SCM since they may have cementitious and/or pozzolanic properties [10]. Therefore, the reduction of the cement consumption and consequently the carbon footprint could be enhanced by the possibility of utilizing SCM. [11]. The use of SCM in concrete is not limited to replacing cement by these industrial by-products. SCM have also been used in the production of eco-friendly concretes replacing both fine and coarse aggregates [12-15].

In view of the beneficial effects of using SCM in LWAC, this article aims to verify the possible influence of the use of different types of SCM in the segregation phenomenon of LWAC. Three different SCM were studied: Silica Fume (SF), Fly Ash (FA) and Posidonia oceanica Ash (PA). A brief review about the origin of each SCM and about the effects caused by its use on the resulting concrete properties of LWAC are presented below.

\subsection{Silica Fume}

$\mathrm{SF}$, a by-product of silicon metal production, is a fine powder which rises as an oxidized vapor from the furnace during the process of manufacturing of the silicon and which is finally condensed upon cooling. [11]. The lower specific gravity of SF when compared to cement, generally induces to a slight decrease in the density of the LWAC when SF is used as partial replacement of cement $[7,16]$. The presence of SF, up to a certain optimum replacement level, due to the high reactivity and micro-filler effect, have positive effect on compressive strength of LWAC [7]. The research of Kilic et al. [17], at all ages of concrete-from 3 days to 3 months-showed that a content of $10 \%$ of SF increased the compressive strength of LWAC when compared to the control concrete without SF. The results of Demirboga et al. [7] showed that the 7-day compressive strength of pumice LWAC presented an enhance up to $27 \%$, when percentages of $10 \%$ and $20 \%$ of SF were incorporated.

The high fineness of SF is known to increase the water demand of conventional concretes [11] and as reported by Sancak et al. [18], this is also generally the same for the case of using in LWAC. The high surface area of the particles requires a higher amount of water to be wetted. Besides this increase in water demand caused by SF, reductions in bleeding [19] and increases of cohesiveness and segregation resistance $[7,20]$ of LWAC were also noticed. Self-compacting LWAC including SF also had it slump flow and V-funnel flow times increased [21]. SF effects are also positive in terms of plastic shrinkage, contributing to the reduction of crack area and crack length of LWAC [19].

\subsection{Fly Ash}

FA, a by-product from coal-fired power plants, is a powder formed by fine particles which are driven out of boiler along with flue gases [11]. As reported in the literature, when used as partial replacement of cement, FA tends to slightly decrease the density of LWAC [7,22-24] due to the lower specific gravity of FA compared to cement. Bogas and Gomes [23] found lesser densities, in fresh state, of concrete mixtures comprising Lightweight Expanded Clay Aggregate (LECA) as coarse aggregate by partially replacing cement with FA. Although FA has pozzolanic properties, the lower compressive strength found in LWAC containing FA reflects its lower reactivity [22,23], particularly at early ages $[7,17,25]$. However, in some cases, at later ages, the compressive strength of LWAC without FA can be overcome by those containing FA, as demonstrated by Lo et al. [22] and Subasi [26].

In general, researchers found that the workability of fresh LWAC was improved [7,20,22], by up to $30 \%$, with the use of FA, mainly because of the rounded shape of FA particles. The spherical shape of FA particles reduces the friction between aggregate and paste leading to the 'ball-bearing' effect making the concrete flow more easily $[7,8,22,23]$. When FA was used in LWAC at $30 \%$ and $50 \%$ cement replacement levels, Shafigh et al. [24] observed agglomeration of the aggregates due to the low water 
to binder ratio $(\mathrm{w} / \mathrm{b})$ as well as fine FA particles used. The problem was solved by increasing the water content of the mixes [24], a solution that is not always possible to apply, since the increase of the water to binder ratio $(\mathrm{w} / \mathrm{b})$ can affect the mechanical properties of structural concretes.

\subsection{Oceanic Posidonia Ash}

Posidonia oceanica is a type of marine phanerogam endemic on Mediterranean coasts [27] and the extensive meadows of this phanerogam are vital to the marine ecosystem [28]. Posidonia oceanica loses its leaves in an annual cycle similar to that of deciduous forests accumulating in large quantities on the beaches due to the effect of waves [29]. Some studies have been carried out with the objective of evaluating the viability of reusing directly Posidonia oceanica residues accumulated in the Mediterranean beaches as a construction material by using its leaves to reinforce biocomposite boards, which could be an alternative to traditional wood-based particleboard [30,31]. Since large quantities of Posidonia oceanica waste generated in the cleaning processes of the beaches are incinerated, several studies have also been carried out to evaluate the possibility of using the Posidonia oceanica ash (PA) after its incineration at different temperatures as a SCM $[29,32,33]$. In addition, Posidonia oceanica has been also valorized as cellulosic fibers [34] and as cellulosic nanoparticles [35]. The use of Posidonia oceanica and PA have shown promising results in mechanical properties, thermal and acoustic behavior and fire resistance [30] but still more research is needed.

\subsection{The Aim of the Study}

The inclusion of different types of SCM had different effects on the workability of LWAC. The high water demand to wet fine particles of SCM like SF, tends to reduce the workability of LWAC [11]. However when FA, a material with cement-like fineness, was added into LWAC as a partial cement replacement, improvements in the workability up to a certain level of replacement were noticed but beyond the optimum level, the substitution reduces significantly the workability of LWAC [11]. Lower yield stress and plastic viscosity generally improve the concrete workability but increase the risk of segregation [36]. Segregation, this tendency of separation of the coarse aggregate from the mortar matrix, is one of the main problems of concrete in a fresh state [37]. In LWAC, the higher the vibration energy applied during casting, the higher the tendency of separation of the aggregates from the mortar matrix, in this case moving towards the top of structural elements, as the LWA have a lower density than the mortar. Among the numerous consequences of the segregation, the strength and durability of structures could be affected [37], since density, compressive strength and elastic modulus of the concrete could suffer variations once the concentration of LWA in some areas of the elements could be different from those expected during design [36].

As aforementioned, the aim of this research is to evaluate the influence of using Silica Fume (SF), Fly Ash (FA) and Posidonia oceanica Ash (PA) in the segregation phenomenon of LWAC.

\section{Experimental Details}

\subsection{Materials Used}

All samples were manufactured with the same water/binder ratio $(\mathrm{w} / \mathrm{b})$ of 0.7 , resulting in $347 \mathrm{~kg} / \mathrm{m}^{3}$ of binder and $243 \mathrm{~kg} / \mathrm{m}^{3}$ of water to produce $1 \mathrm{~m}^{3}$ of concrete, considering both free and absorbed water, since the aggregates had been oven dried. The water/binder ratio of 0.7 was adopted after an initial test considering water/binder ratios of $0.6 ; 0.65$ and 0.7 from which it was concluded that ratios lower than 0.7 would hinder the occurrence of segregation (30s of vibration), especially in the case concretes containing SF. CEM I 52.5 R (CEMEX, Madrid, Spain) cement with an absolute density of $3176 \mathrm{~kg} / \mathrm{m}^{3}$ was used for all the concretes. Figure 1 shows the supplementary materials used in this work. The SF used was a dry uncompacted powder from Elkem Materials with $\mathrm{SiO}_{2}$ content of $88.53 \%$ (Table 1) with an absolute density of $111 \mathrm{~kg} / \mathrm{m}^{3}$. FA from the thermoelectric power plant Andorra-Teruel (Spain), with an absolute density of $2313 \mathrm{~kg} / \mathrm{m}^{3}$. PA used for cement 
replacement was obtained directly from natural deposits accumulated on a beach from Alicante (Spain). Prior to incineration, the Posidonia oceanica was cleaned with tap water to remove the particles adhered (sand and salts) to the leaves. Afterwards, the leaves were incinerated at $1000{ }^{\circ} \mathrm{C}$ as recommended by García-Andreu et al. [29] and were milled. PA used passed through the sieve $0.075 \mathrm{~mm}$ with an absolute density of $2720 \mathrm{~kg} / \mathrm{m}^{3}$. The absolute density of the cement and SCMs was characterized applying the pycnometer method, in accordance with UNE-EN 1097-7 [38].

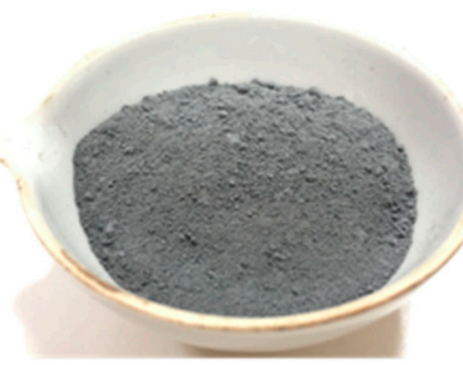

(a)

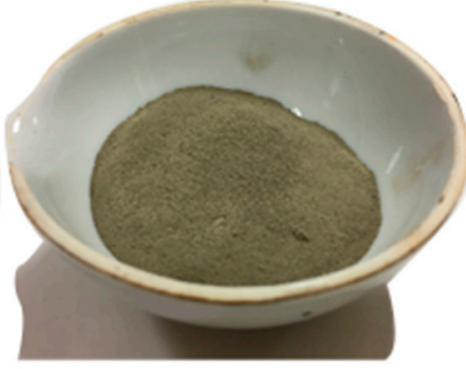

(b)

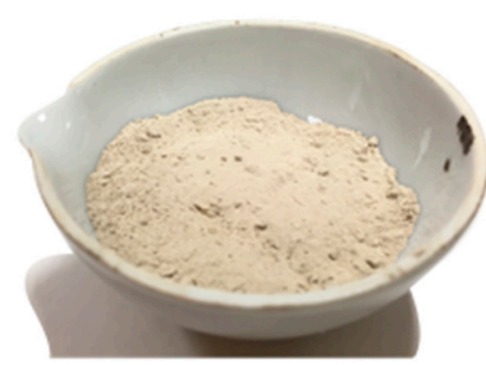

(c)

Figure 1. Supplementary cementing materials (SCM) has been used to replace partially the cement amount in this study, (a) Silica Fume (SF); (b) Fly Ash (FA); (c) Posidonia oceanica Ash (PA).

Table 1. Chemical characteristics of SF, FA and PA.

\begin{tabular}{cccc}
\hline Component & SF & FA & PA \\
\hline $\mathrm{Na}_{2} \mathrm{O}$ & 0.30 & - & 0.62 \\
$\mathrm{MgO}$ & 0.91 & 1.43 & 11.24 \\
$\mathrm{Al}_{2} \mathrm{O}_{3}$ & 0.30 & 23.89 & 0.88 \\
$\mathrm{SiO}_{2}$ & 88.53 & 39.68 & 10.20 \\
$\mathrm{P}_{2} \mathrm{O}_{5}$ & 0.14 & 0.42 & 0.50 \\
$\mathrm{SO}_{3}$ & 0.42 & 0.45 & 6.04 \\
$\mathrm{Cl}^{-}$ & - & - & 0.57 \\
$\mathrm{~K}_{2} \mathrm{O}$ & 0.51 & 1.18 & 0.07 \\
$\mathrm{CaO}$ & 2.81 & 4.38 & 49.59 \\
$\mathrm{TiO}_{2}$ & 0.10 & 1.02 & 0.18 \\
$\mathrm{Fe}_{2} \mathrm{O}_{3}$ & 0.21 & 11.39 & 1.58 \\
$\mathrm{SrO}$ & - & 0.13 & - \\
$\mathrm{CuO}$ & - & - & 0.04 \\
$\mathrm{SrO}$ & 0.03 & - & 0.32 \\
$\mathrm{BaO}$ & 0.58 & 0.90 & 0.51 \\
$\mathrm{WO}_{3}$ & 0.21 & 0.34 & 0.15 \\
L.O.I. ${ }^{1}$ & 4.95 & 14.79 & 17.52 \\
\hline
\end{tabular}

The chemical composition of the SF, FA, and PA are given in Table 1 and it was obtained by X-ray fluorescence $(\mathrm{XRF})$ using $\mathrm{X}$-ray fluorescence $(\mathrm{XRF})$ with an X-ray sequential spectrometer PHILIPS MAGIC PRO (Philips Ibérica, Madrid, Spain). As can be seen in Table 1, the L.O.I. value for FA and PA samples were high according to UNE EN 450-1 [39]—assuming this parameter provides a good estimation of carbon content-and it could affect the water requirement and the rheological properties [40]. The crystallographic phases of SF, FA and PA were identified by using X-ray diffraction (XRD) carried out with a Bruker D8-Advance diffractometer (Bruker Española S.A., Madrid, Spain). The X-ray tube was operated at $40 \mathrm{kV}$ and $40 \mathrm{~mA}$, and the spectra were registered with angles from $4^{\circ}$ to $60^{\circ}$ at $0.05^{\circ}$ stepping intervals in $\Theta-\Theta$ mode. As shown in the powder X-ray diffraction (XRD) patterns in Figure 2 the shoulder-shaped diffractogram of SF in Figure 2, without any noticeable peak, suggests that this sample is primarily amorphous (appearance of a broad and diffuse "halo" pattern [41,42] and the diffractogram does not show a defined Bragg reflection [43]). Although the samples present a high amorphous phase content, only the crystalline phases were determined (quartz, 
sillimanite and hematite in FA and calcite, calcium hydroxide, anhydrite, stishovite and magnesite in PA).

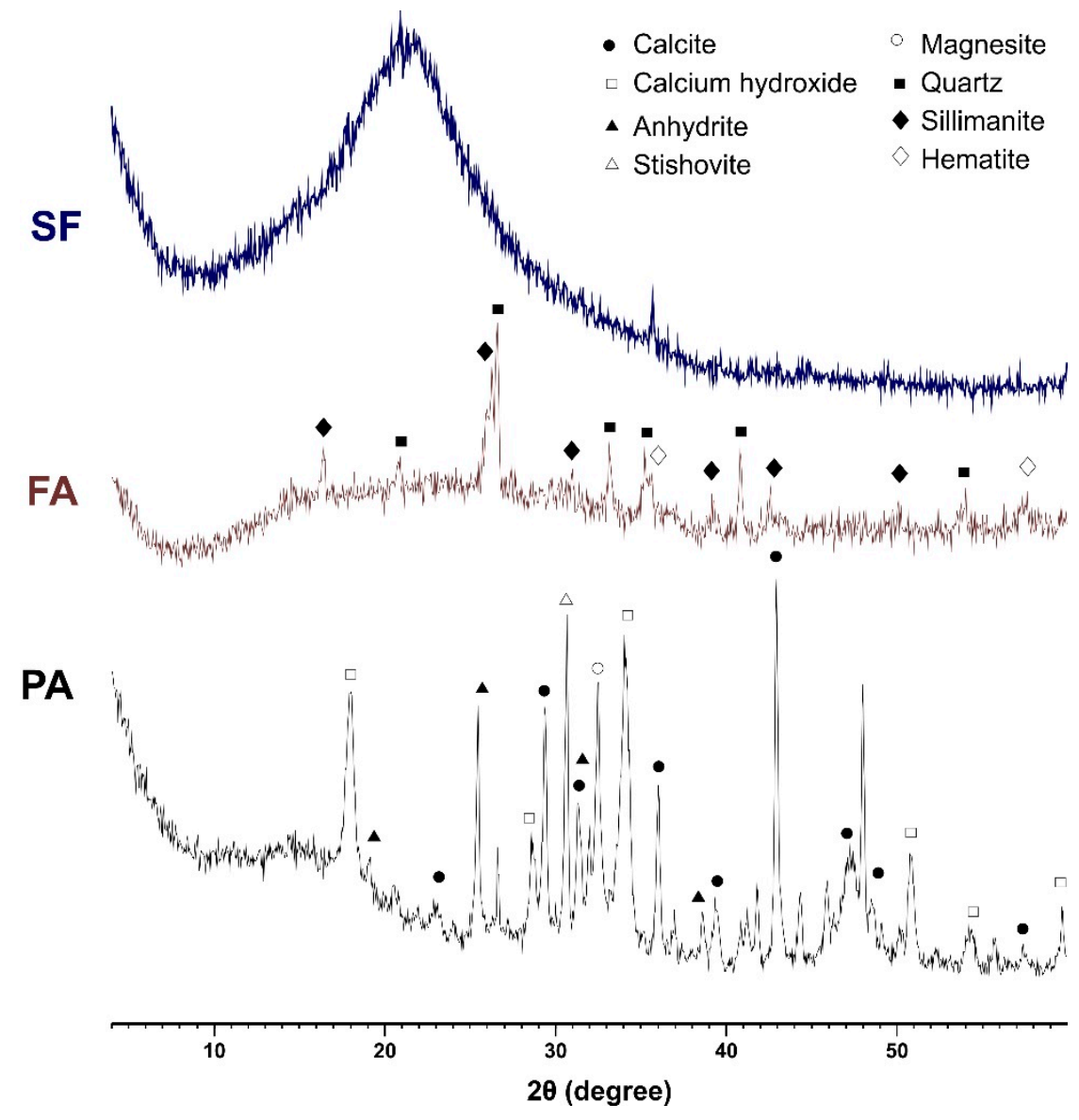

Figure 2. XRD patterns of SF (silica fume), FA (fly ash) and PA (Posidonia oceanica ash).

The lightweight aggregate (LWA) used in this study was expanded clay type commercially manufactured. The bulk density of the LWAs was obtained according to the procedure described in the standard UNE EN 1097-3 [44]. In addition, the density of the particles in the dry state was determined by the methodology proposed by Fernández-Fanjul et al. [45], the absorption of water at $24 \mathrm{~h}$ according to the UNE EN 1097-6 [46] (pre-dried particles and in distilled water). The particle size ranges from 8 to $11.2 \mathrm{~mm}$ with a round but irregular shape. The aggregate yielded a water absorption of $23 \%$ and $27 \%$ at $1 \mathrm{~h}$ and $24 \mathrm{~h}$, respectively.

\subsection{Mix Proportions}

The Fanjul method [47] was used for calculating the mixture proportions. Initially a concrete target density of $1800 \mathrm{~kg} / \mathrm{m}^{3}$ was defined to produce the control mixture. For each SCM, three mixtures were prepared, considering three different percentage substitutions of cement: $5 \%, 10 \%$ and $15 \%$ by weight. For each mixture, the dosage was calculated applying the method proposed by Fernández-Fanjul [47], considering the resulting density $\left(\rho_{R}\right)$ of the cementitious materials, calculated according to the equation 1 were $\mathrm{R}$ is the percentage replacement of cement, and $\rho_{S C M}$ and $\rho_{\text {cement }}$, are the SCM and cement densities respectively. The values for each combination are shown in Table 2 .

$$
\rho_{R}=R \cdot \rho_{S C M}+(1-R) \cdot \rho_{c e m e n t}
$$


Table 2. Mixtures proportions used to produce $1 \mathrm{~m}^{3}$ of concrete.

\begin{tabular}{|c|c|c|c|c|c|c|}
\hline Concrete & Type of SCM & $\begin{array}{c}\text { Water } \\
\left(\mathrm{kg} / \mathrm{m}^{3}\right)\end{array}$ & $\begin{array}{l}\text { Cement } \\
\left(\mathrm{kg} / \mathrm{m}^{3}\right)\end{array}$ & $\begin{array}{c}\mathrm{SCM} \\
\left(\mathrm{kg} / \mathrm{m}^{3}\right)\end{array}$ & $\begin{array}{c}\text { LWA } \\
\left(\mathrm{kg} / \mathrm{m}^{3}\right)\end{array}$ & $\begin{array}{c}\text { Sand } \\
\left(\mathrm{kg} / \mathrm{m}^{3}\right)\end{array}$ \\
\hline Control & - & 243 & 347 & 0 & 109 & 1100 \\
\hline SF5 & SF & 243 & 330 & 17 & 106 & 1104 \\
\hline SF10 & SF & 243 & 312 & 35 & 102 & 1107 \\
\hline SF15 & SF & 243 & 295 & 52 & 98 & 1111 \\
\hline FA5 & FA & 243 & 330 & 17 & 109 & 1101 \\
\hline FA10 & FA & 243 & 312 & 35 & 108 & 1102 \\
\hline FA15 & FA & 243 & 295 & 52 & 107 & 1103 \\
\hline PO5 & $\mathrm{PO}$ & 243 & 330 & 17 & 109 & 1100 \\
\hline PO10 & $\mathrm{PO}$ & 243 & 312 & 35 & 109 & 1100 \\
\hline PO15 & $\mathrm{PO}$ & 243 & 295 & 52 & 108 & 1100 \\
\hline
\end{tabular}

The same mixtures proportions used to produce the concrete samples were used to produce their respective mortar samples, in this case not taking into consideration the LWA content and reducing the water content applying a correction due to the aggregate water absorption. The water absorption of $23 \%$ at $1 \mathrm{~h}$ was considered in this correction. The values for each combination are shown in Table 3 .

Table 3. Mixtures proportions used to produce $1 \mathrm{~m}^{3}$ of mortar.

\begin{tabular}{|c|c|c|c|c|c|}
\hline Concrete & Type of SCM & $\begin{array}{c}\text { Water } \\
\left(\mathrm{kg} / \mathrm{m}^{3}\right)\end{array}$ & $\begin{array}{l}\text { Cement } \\
\left(\mathrm{kg} / \mathrm{m}^{3}\right)\end{array}$ & $\begin{array}{c}\text { SCM } \\
\left(\mathrm{kg} / \mathrm{m}^{3}\right)\end{array}$ & $\begin{array}{c}\text { Sand } \\
\left(\mathrm{kg} / \mathrm{m}^{3}\right)\end{array}$ \\
\hline Control & - & 218 & 347 & 0 & 1100 \\
\hline SF5 & SF & 219 & 330 & 17 & 1104 \\
\hline SF10 & SF & 219 & 313 & 35 & 1107 \\
\hline SF15 & SF & 220 & 295 & 52 & 1111 \\
\hline FA5 & FA & 218 & 330 & 17 & 1101 \\
\hline FA10 & FA & 218 & 313 & 35 & 1102 \\
\hline FA15 & FA & 218 & 295 & 52 & 1103 \\
\hline PO5 & $\mathrm{PO}$ & 218 & 330 & 17 & 1100 \\
\hline PO10 & $\mathrm{PO}$ & 218 & 313 & 35 & 1100 \\
\hline PO15 & $\mathrm{PO}$ & 218 & 295 & 52 & 1100 \\
\hline
\end{tabular}

\subsection{Test Methods}

Figures 3 and 4 summarize the procedure used to carry out the research. For each mortar sample, the consistency of fresh mortar (Mc) was estimated according to UNE-EN 1015-3 [48] and the fresh densities $\left(\rho_{\text {mortar }}\right)$ of the samples were obtained according to UNE-EN 1015-6 [49] (Figure 3b).

\section{MORTAR SAMPLES}

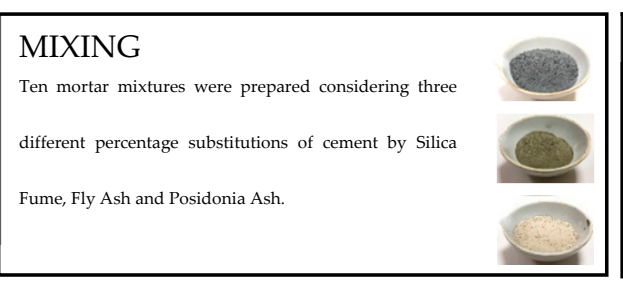

(a)

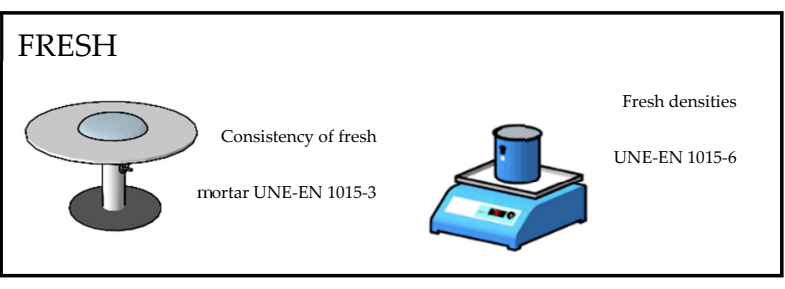

(b)

Figure 3. Flowchart of the experimental methodology used in this study to evaluate the fresh properties of mortar: (a) Mixing; (b) Consistency of fresh mortar and fresh densities.

Before casting the concrete samples, the concrete consistency (Cc) was measured using the slump (Figure $4 \mathrm{~b}$ ) test according to UNE-EN 12350-2 [50] and the fresh densities $\left(\rho_{\text {fresh }}\right)$ of the samples were obtained according to UNE-EN 12350-5 [51]. The cylindrical samples (Ø150mm and 300mm height) 
were compacted using an electric needle vibrator of $18,000 \mathrm{rpm} / \mathrm{min}$ and a $\varnothing 25 \mathrm{~mm}$ needle and were vibrated for $30 \mathrm{~s}$ in one layer (Figure 4c). After being made and cured in the water at a temperature of $20 \pm 1^{\circ} \mathrm{C}$ for 28 days, the specimens were saw-cut through its longitudinal axis and their sections were photographed for the subsequent image analysis (Figure $4 \mathrm{~d}$ ).

\section{CONCRETE}

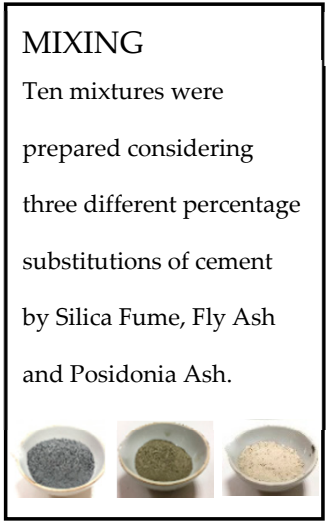

(a)

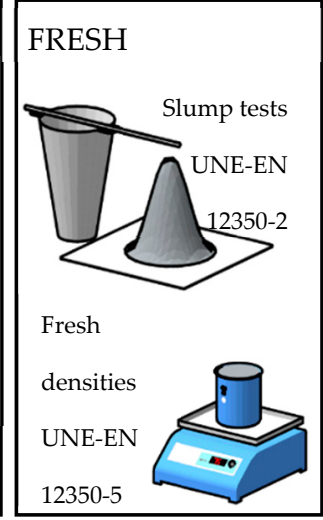

(b)

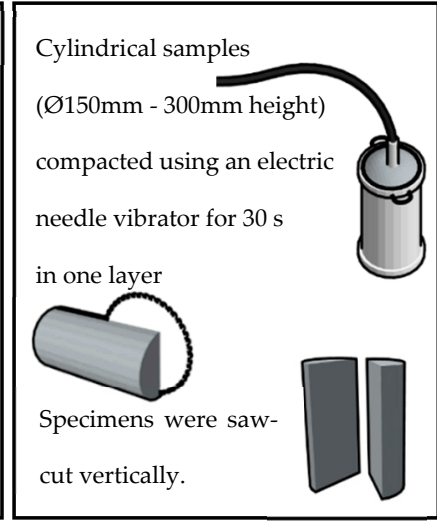

(c)

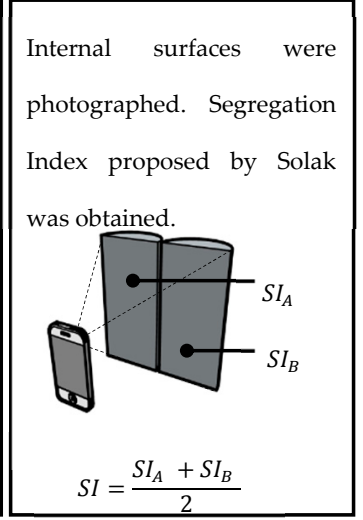

(d)

Figure 4. Flowchart of the experimental methodology used in this study to evaluate the fresh properties of concrete and the segregation tendency: (a) Mixing; (b) Slump testes and fresh densities; (c) Casting and saw-cutting; (d) Photographing and image analysis for calculating segregation index.

The photographs were taken in a natural light environment using a 12-megapixel camera from an iPhone SE, with a resolution of $3024 \times 4032$ pixels and $72 \mathrm{dpi}$, ISO-80, exposure time of $1 / 33 \mathrm{~s}$ and aperture of $\mathrm{f} / 2.2$ and without flash.

The images of the sections were used to calculate the volumetric segregation index (SI) according Solak [52] applying and image analysis technique. ImageJ, a freeware software, was used to process the images and to determine the black and white matrices. From the original images, some contrast, threshold and noise adjustments were made (Figure 5b), and the image was binarized (Figure 5c). Internal voids of the aggregates were filled (Figure 5d). ImageJ was used to transform the image in a black and white matrix (Figure 5e), where each pixel of the image is equivalent to one element of the matrix.

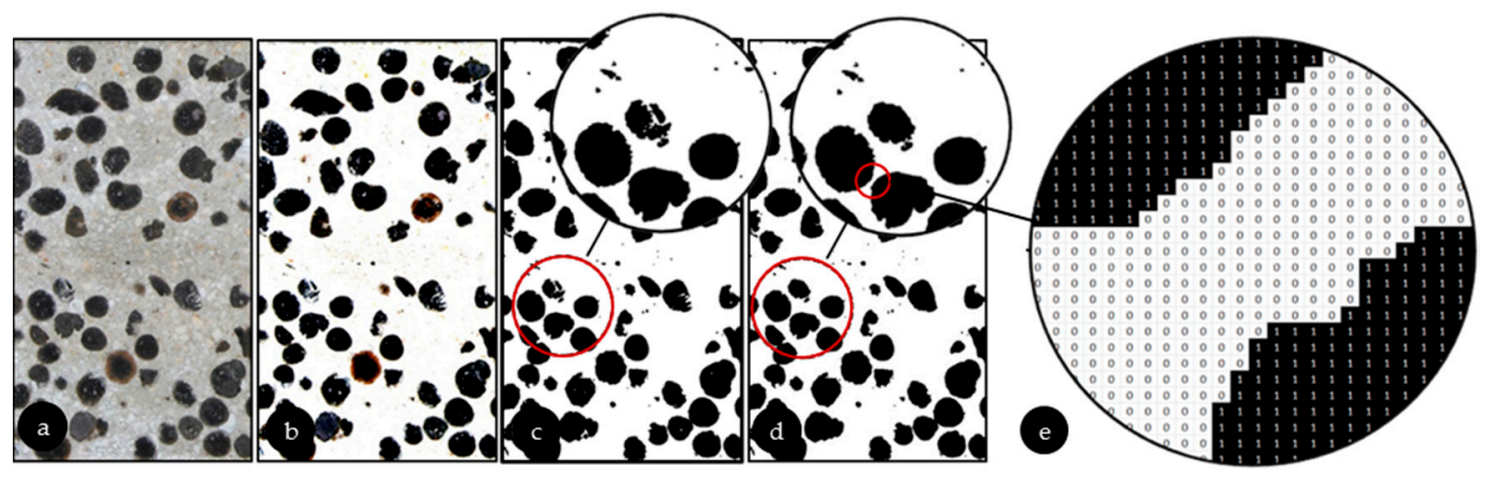

Figure 5. (a) Original image. (b) Contrast, threshold and noise adjustments. (c) Binarization (d) Fill holes. (e) Black and white matrix.

White points (number 0) were classified as mortar and black points (number 1) were classified as aggregate. Using the results from these matrices, applying a point counting method the segregation index of Solak [52] was calculated for each section. SI is an index that analyzes the distribution of aggregates by comparing the concentration of aggregates of sub-sections of the sample with the total 
concentration of aggregates of the sample. Values close to $0 \%$ indicate low levels of segregation and values close to $100 \%$ indicate high levels of segregation. For each sample, the mean SI was calculated considering the results of each half. Figure 6 shows the samples after being saw cut.

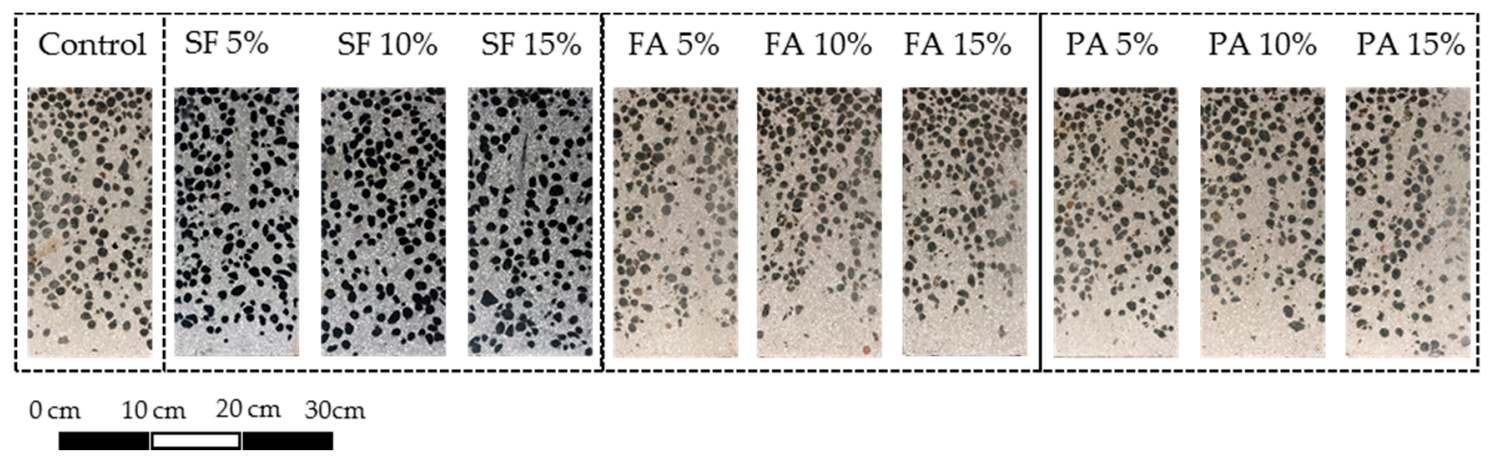

Figure 6. Aspect of the halves after saw cutting.

\section{Results and Discussion}

As described by Navarrete [53], the density difference between aggregate and mortar $\left(\Delta_{\rho}\right)$ play an important role in the phenomenon of segregation as well as the size and shape of the LWA. For normal weight concretes, a relationship between gravitational force and drag force determines the segregation of the aggregates due to vibration [54]. Segregation is facilitated by higher values of gravitation forces, which are related to the volume of the aggregate and $\Delta_{\rho}$ value. The use of LWA with a particle density higher than $1100 \mathrm{~kg} / \mathrm{m}^{3}$ can avoid the serious segregation of fresh self-consolidating LWAC [55]. On the other side, higher values of drag force, which is influenced by the mortar viscosity and aggregate shape, reduce segregation.

Substitution of cement by other materials with different densities results in a variation of the density of the mortar matrix $\left(\rho_{\text {mortar }}\right)$, consequently affecting $\Delta_{\rho}$ and may eventually affect the segregation. The substitution of cement by other materials with different grain size, considering a constant water binder ratio, may also result in a variation of the consistency of concrete and the viscosity of the mortar matrix, which may contribute to increase or reduce segregation.

Similar to results observed in other research [7], it can be seen that adding SF resulted in the rapid reduction of the workability of the LWAC. This reduction is observed analyzing the reductions on mortar consistencies (Mc) (Figure 7a) and slump tests (Cc) (Figure 7b). The partial substitution of cement by SF also resulted in a reduction of $\rho_{\text {mortar }}$ of $1.26 \%, 2.59 \%$ and $8.04 \%$ for SF5, SF10 and SF15, respectively, leading to reductions on $\Delta_{\rho}$ (Figure 7c) contributing to the segregation resistance, once concrete mixtures with a greater $\Delta_{\rho}$ tend to segregate more [34,35]. The combined effect of reducing $\rho_{\text {mortar }}, \mathrm{Mc}$ and Cc contributed to the segregation-resistance of the concrete since the segregation indexes decreased with the increase of the SCM weight fraction (Figure 7d).

As observed in other research [8], the FA improves the workability of the concrete due to its "shape effect". This phenomenon is observed analyzing the variations on mortar consistencies (Mc) (Figure 7a) and slump tests (Cc) (Figure 7b). When compared to SF, the partial substitution of cement by FA also resulted in a small reduction of $\rho_{\text {mortar }}$ of $0.15 \%, 0.80 \%$ and $1.64 \%$ for FA5, FA10 and FA15, respectively, leading to little reductions on $\Delta_{\rho}$ (Figure 7c). In this case, even with reductions of $\Delta_{\rho}$ the workability of the concrete seems to be more relevant to describe the segregation once Mc and Cc increased with the increase of SCM weight fraction, as is the case of concrete segregation (Figure 7d). 


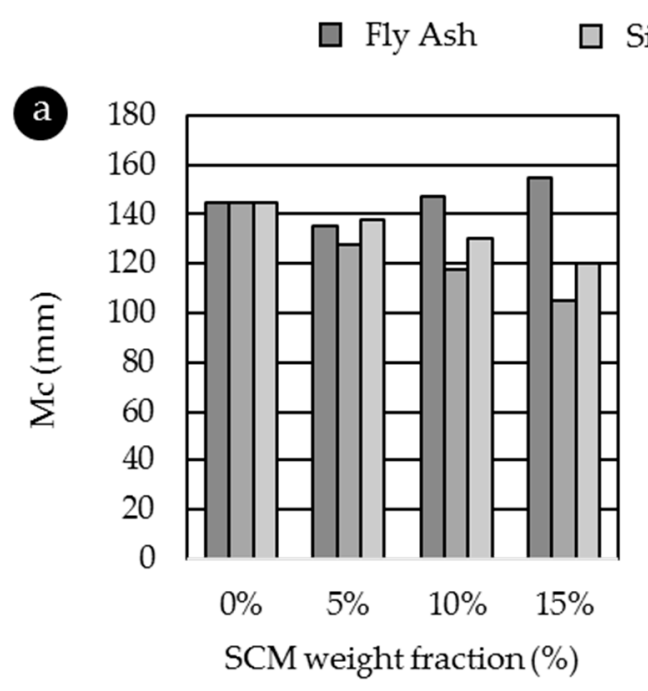

SilicaFume $\quad \square$ Posidonia Ash
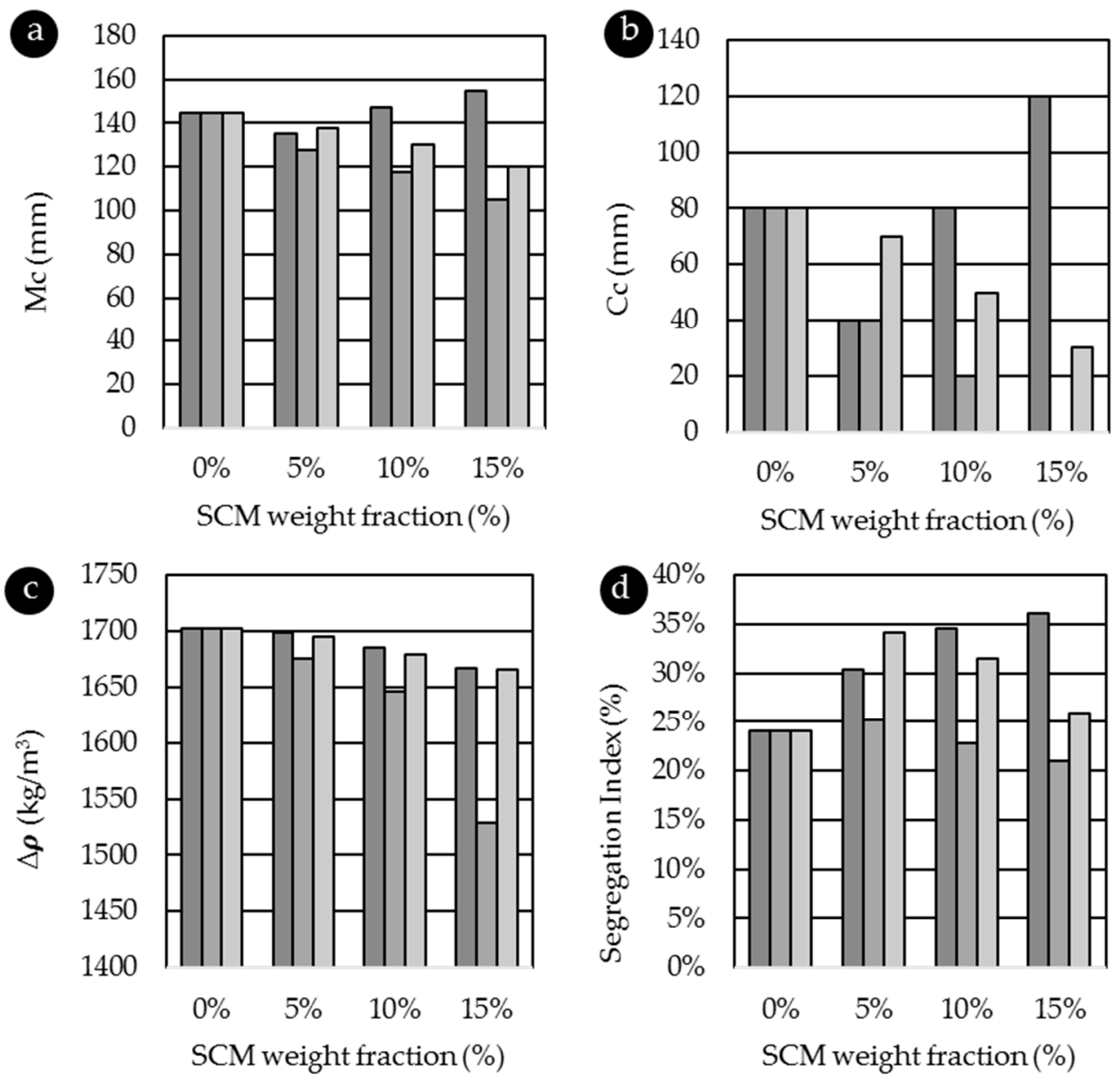

Figure 7. Results for cement replacements by admixtures (a) Mortar consistency variations; (b) Concrete consistency variation; (c) Variations on density differences between aggregate and mortar; (d) Segregation variations.

Similar to SF, it can be seen that adding PA resulted in a reduction of the workability of the LWAC. This reduction was not as intense as the reduction observed in SF samples, but the results are consistent with previous studies adding PA in cement mortars, were samples with added ash demand more water to achieve a determined consistency [29]. In LWAC it is expected that this phenomenon is even more intense, since part of the water is still absorbed by the LWA. The variations on workability were observed analyzing the variations on mortar consistencies (Mc) (Figure 7a) and slump tests (Cc) (Figure 7b). The substitution of cement by PA almost did not affect $\rho_{\text {mortar }}$ (reductions of $0.33 \%, 1.10 \%$ and $1.69 \%$ for PA5, PA10 and PA15, respectively), leading to little reductions on $\Delta_{\rho}$ (Figure 7c). Initially, adding PA in substitution of cement, for low percentages of substitution, seems to increase the segregation tendency, even with reductions in workability and $\Delta_{\rho}$, which is contrary to the effects found in FA and SF. Once the replacement percentage increases, segregation tends to decrease (Figure 7d) indicating that other rheological parameters may affect the segregation phenomenon.

Although it is clearly observed that increased workability, both concrete and mortar, leads to increased segregation (Figures 8 and 9 respectively), these variations in consistency alone do not account for variations in the segregation phenomenon. In order to check the separated and combined effect of Mc, Cc and $\Delta_{\rho}$, a statistical analysis was performed in XLSTAT by Addinsoft. First the test of normality of Shapiro-Wilk was performed, and it results ( $p$-value of $0.40>$ alpha of 0.05 ) confirms that the data are from a normally distributed population. Considering that the parameters analyzed were Mc, $\mathrm{Cc}$ and $\Delta_{\rho}$ and not the SCM weight fraction itself, the SI data from the different mixtures 
were grouped in the statistical analysis, once its results indicated that, regardless of the SCM used, there was a possible relation between this parameters and SI. Therefore, Simple Linear Regression (SLR) models and two Multiple Linear Regression (MLR) models were developed. Their parameters, equations and results are shown in Table 4.

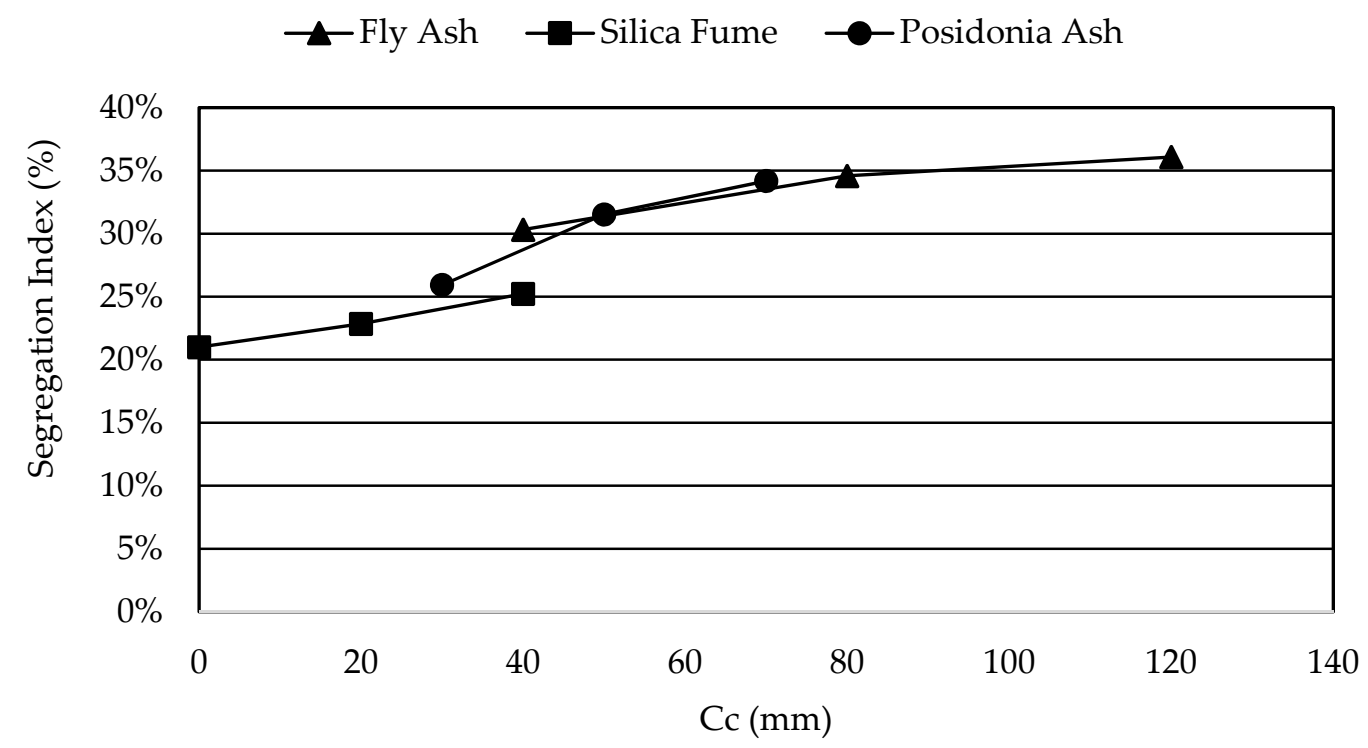

Figure 8. Variations on concrete consistency versus segregation.

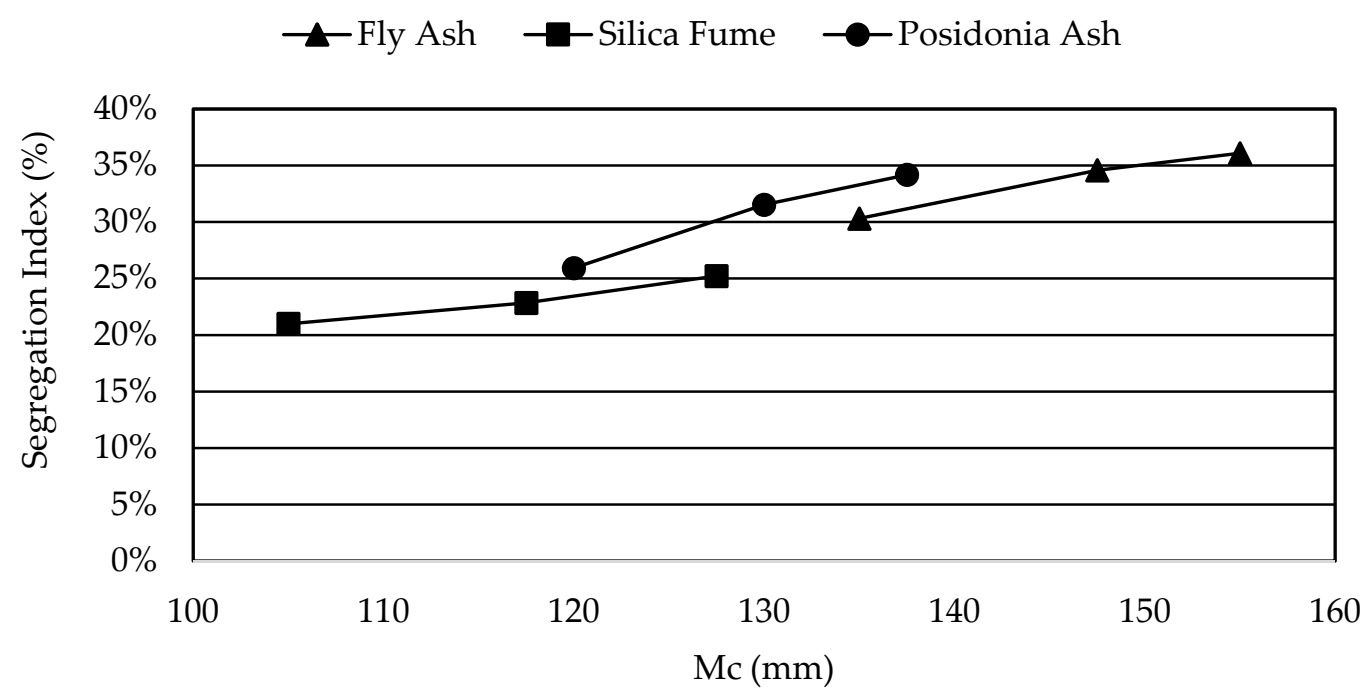

Figure 9. Variations on mortar consistency versus segregation.

Table 4. Linear regression models developed.

\begin{tabular}{cccc}
\hline Model & Variables & Equation & $\mathbf{R}^{2 *}$ \\
\hline I & $\Delta_{\rho}\left(\mathrm{kg} / \mathrm{m}^{3}\right)$ & SI $(\%)=5.7914 \times 10^{-4 *} \Delta_{\rho}-0.6782$ & 0.296 \\
II & $\mathrm{Cc}(\mathrm{mm})$ & SI $(\%)=0.0012^{*} \mathrm{Cc}+0.223$ & 0.586 \\
III & Mc $(\mathrm{mm})$ & SI $(\%)=2.7486 \times 10^{-3 *} \mathrm{Mc}-7.6997 \times 10^{-2}$ & 0.597 \\
IV & $\mathrm{Cc}(\mathrm{mm})$ and $\Delta_{\rho}\left(\mathrm{kg} / \mathrm{m}^{3}\right)$ & $\mathrm{SI}(\%)=1.0558 \times 10^{-3 *} \mathrm{Cc}+1.5100 \times 10^{-4 *} \Delta_{\rho}-2.1495 \times 10^{-2}$ & 0.599 \\
V & $\mathrm{Mc}(\mathrm{mm})$ and $\Delta_{\rho}\left(\mathrm{kg} / \mathrm{m}^{3}\right)$ & $\mathrm{SI}(\%)=2.8041 \times 10^{-3 *} \mathrm{Mc}-2.3158 \times 10^{-5 *} \Delta_{\rho}-0.0458$ & 0.597 \\
\hline & &
\end{tabular}

For the SLR Model I, given the $\mathrm{R}^{2}, 30 \%$ of the variability of the dependent variable SI (\%) is explained by the explanatory variable $\Delta_{\rho}$. For the SLR Models II and III, given the $\mathrm{R}^{2}, 59 \%$ and $60 \%$, respectively, of the variability of the dependent variable SI (\%) is explained by the explanatory variable 
(Cc and Mc, respectively). For MLR Models IV and V, given the $\mathrm{R}^{2}, 60 \%$, for both situations, of the variability of the dependent variable SI (\%) is explained by the 2 explanatory variables (Cc and $\Delta_{\rho}$ for Model 4 , and Mc and $\Delta_{\rho}$ for Model 5). As can be seen in Table $4, R^{2}$ and according to the Evans scale [56] the correlation of Model I is considered weak, however the correlation of the Models II, III, IV and V are considered moderate [56] indicating that $\mathrm{Cc}$ and Mc explain better the segregation index than $\Delta_{\rho}$. In addition, MLR combining $\Delta_{\rho}$ with Cc and $\Delta_{\rho}$ with Mc also explain better SI than Model I. In the mixtures evaluated in this study, cement replacement by admixtures did not cause significant effects on mortar density, and consequently did not cause significant variations in $\Delta_{\rho}$, which possibly explains the bad correlation between the Model I and the experimental results (red color in Figure 10. However since the segregation index variability is slightly better explained by the model IV (blue color in Figure 10) than model II (yellow color in Figure 10), and considering the results of Navarrete-Lopez [53], the combined effect of the variations of the viscosity of the mortar matrix (indicated in this case by $\mathrm{C} c$ ) and $\Delta_{\rho}$ could indicate that the segregation tendency of a concrete mixture is more related to the combined effect of both parameters than to each individual parameter.

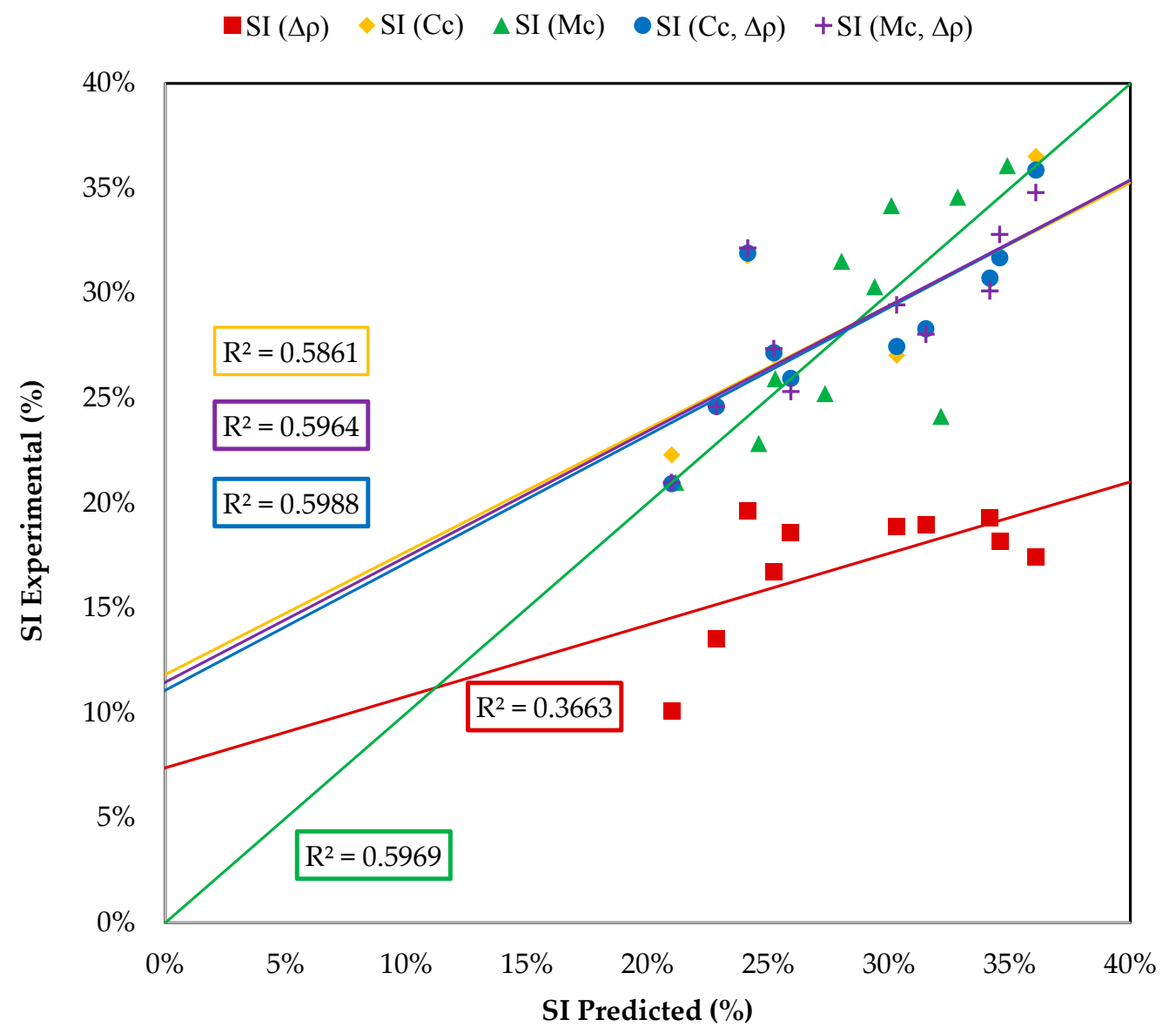

Figure 10. Segregation index obtained experimentally versus predicted segregation index and $\mathrm{R}^{2}$ between both of them.

\section{Conclusions}

This study presents an experimental study on segregation in lightweight aggregate concretes (LWAC) analyzing different mixtures containing supplementary cementing materials. From the results presented in this study the following conclusions are drawn:

It can be seen that adding silica fume resulted in a reduction of the workability and slightly reduction of the density of the LWAC. The combined effect of reducing the density, concrete consistency 
and mortar consistency contributed to the segregation-resistance of the concrete, since the segregation indexes decreased with the increase of the SCM weight fraction.

Fly ash improved the workability of the concrete and almost did not affect the density of the mortar matrix. In this case variations in the workability of the concrete due to the substitution of cement by fly ash seem to be more relevant to describe the segregation than the variations in the mortar matrix. Even though more mixtures must be studied, the results of this paper indicated that high levels of substitution of cement by fly ash could lead to segregation of the aggregates.

Adding Posidonia ash resulted in a reduction of the workability of the LWAC. In this case variations in the workability of the concrete due the substitution of cement by Fly Ash seems to be more relevant to describe the segregation than the variation of the density of the mortar matrix. In spite of the fact that all the studied mixtures presented higher segregation indexes than control, when the replacement percentage increases, segregation tends to decrease, indicating that other rheological parameters may also affect the segregation phenomenon.

Author Contributions: Conceptualization, A.M.S.; Data curation, A.M.S.; Formal analysis, A.M.S. and A.J.T.-A.; Funding acquisition, A.J.T.-A. and J.M.S.; Investigation, A.M.S., A.J.T.-A., J.M.S. and V.E.G.-V.; Methodology, A.M.S. and A.J.T.-A.; Project administration, J.M.S.; Supervision, J.M.S. and V.E.G.-V.; Validation, A.M.S.; Writing—original draft, A.M.S.; Writing—review and editing, A.J.T.-A., J.M.S. and V.E.G.-V.

Funding: This research was supported by the University of Alicante (GRE13-03) and (VIGROB-256).

Conflicts of Interest: The authors declare no conflict of interest.

\section{References}

1. The European Commission Directive (EU) 2018/844 of the European Parliament and of the Council of 30 May 2018 Amending Directive 2010/31/EU on the Energy Performance of Buildings and Directive 2012/27/EU on Energy Efficiency. Available online: https:/ / eur-lex.europa.eu/legal-content/EN/TXT/?uri=uriserv\% 3AOJ.L_.2018.156.01.0075.01.ENG (accessed on 20 November).

2. Park, D.J.; Yu, K.H.; Yoon, Y.S.; Kim, K.H.; Kim, S.S. Analysis of a building energy efficiency certification system in Korea. Sustainability 2015, 7, 16086-16107. [CrossRef]

3. Real, S.; Gomes, M.G.; Moret Rodrigues, A.; Bogas, J.A. Contribution of structural lightweight aggregate concrete to the reduction of thermal bridging effect in buildings. Constr. Build. Mater. 2016, 121, 460-470. [CrossRef]

4. Álavarez Palacios, G.; Saez Bravo, E. Hormigón Ligero: Aspectos Técnicos y Estéticos; Universidad Politécnica de Valencia: Valencia, Spain, 2012; p. 148.

5. The European Union per Regulation 305/2011; Directive 98/34/EC, D. 2004/18/EC Eurocode 2: Design of Concrete Structures. Part 1-1: General Rules and Rules for Buildings. Section 11: Lightweight Aggregated Concrete Structures; European Union: Brussels, Belgium, 2010.

6. ACI Committee 213. ACI 213R-03-Guide for Structural Lightweight-Aggregate Concrete; American Concrete Institute: Farmington Hills, MI, USA, 2004.

7. Demirboğa, R.; Örüng, İ.; Gül, R. Effects of expanded perlite aggregate and mineral admixtures on the compressive strength of low-density concretes. Cem. Concr. Res. 2001, 31, 1627-1632. [CrossRef]

8. Chen, B.; Liu, J. Experimental application of mineral admixtures in lightweight concrete with high strength and workability. Constr. Build. Mater. 2008, 22, 1108-1113. [CrossRef]

9. Coppola, L.; Coffetti, D.; Crotti, E. Plain and ultrafine fly ashes mortars for environmentally friendly construction materials. Sustainability 2018, 10, 874. [CrossRef]

10. Papadakis, V.; Tsimas, S. Supplementary cementing materials in concrete: Part I: Efficiency and design. Cem. Concr. Res. 2002, 32, 1525-1532. [CrossRef]

11. Mo, K.H.; Ling, T.-C.; Alengaram, U.J.; Yap, S.P.; Yuen, C.W. Overview of supplementary cementitious materials usage in lightweight aggregate concrete. Constr. Build. Mater. 2017, 139, 403-418. [CrossRef]

12. Kim, G.M.; Jang, J.G.; Khalid, H.R.; Lee, H.K. Water purification characteristics of pervious concrete fabricated with CSA cement and bottom ash aggregates. Constr. Build. Mater. 2017, 136, 1-8. [CrossRef]

13. Papadakis, V.G. Effect of supplementary cementing materials on concrete resistance against carbonation and chloride ingress. Cem. Concr. Res. 2000, 30, 291-299. [CrossRef] 
14. Alnahhal, M.F.; Alengaram, U.J.; Jumaat, M.Z.; Alqedra, M.A.; Mo, K.H.; Sumesh, M. Evaluation of industrial by-products as sustainable pozzolanic materials in recycled aggregate concrete. Sustainability 2017, 9, 767. [CrossRef]

15. Letelier, V.; Ortega, J.M.; Tarela, E.; Muñoz, P.; Henríquez-Jara, B.I.; Moriconi, G. Mechanical performance of eco-friendly concretes with volcanic powder and recycled concrete aggregates. Sustainability 2018, 10, 3036. [CrossRef]

16. Sancak, E.; Dursun Sari, Y.; Simsek, O. Effects of elevated temperature on compressive strength and weight loss of the light-weight concrete with silica fume and superplasticizer. Cem. Concr. Compos. 2008, 30, 715-721. [CrossRef]

17. Kılıç, A.; Atiş, C.D.; Yaşar, E.; Özcan, F. High-strength lightweight concrete made with scoria aggregate containing mineral admixtures. Cem. Concr. Res. 2003, 33, 1595-1599. [CrossRef]

18. Sancak, E.; Simsek, O.; Apay, A.C. A comparative study on the bond performance between rebar and structural lightweight pumice concrete with/without admixture. Int. J. Phys. Sci. 2011, 6, 3437-3454.

19. Yeginobali, A.; Sobolev, K.G.; Soboleva, S.V.; Tokyay, M. High Strength Natural Lightweight Aggregate Concrete with Silica Fume. Spec. Publ. 1998, 178, 739-758.

20. Demirboğa, R.; Gül, R. Thermal conductivity and compressive strength of expanded perlite aggregate concrete with mineral admixtures. Energy Build. 2003, 35, 1155-1159. [CrossRef]

21. Güneyisi, E.; Gesoğlu, M.; Booya, E. Fresh properties of self-compacting cold bonded fly ash lightweight aggregate concrete with different mineral admixtures. Mater. Struct. Constr. 2012, 45, 1849-1859. [CrossRef]

22. Lo, T.Y.; Cui, H.Z.; Li, Z.G. Influence of aggregate pre-wetting and fly ash on mechanical properties of lightweight concrete. Waste Manag. 2004, 24, 333-338. [CrossRef] [PubMed]

23. Akçaözoğlu, S.; Atiş, C.D. Effect of Granulated Blast Furnace Slag and fly ash addition on the strength properties of lightweight mortars containing waste PET aggregates. Constr. Build. Mater. 2011, 25, 4052-4058. [CrossRef]

24. Shafigh, P.; Alengaram, U.J.; Mahmud, H.B.; Jumaat, M.Z. Engineering properties of oil palm shell lightweight concrete containing fly ash. Mater. Des. 2013, 49, 613-621. [CrossRef]

25. Shannag, M.J. Characteristics of lightweight concrete containing mineral admixtures. Constr. Build. Mater. 2011, 25, 658-662. [CrossRef]

26. Subaşi, S. The effects of using fly ash on high strength lightweight concrete produced with expanded clay aggregate. Sci. Res. Essays 2009, 4, 275-288.

27. Belzunce, M.; Navarro Cerrillo, R.; Rapoport, H. Seed and early plantlet structure of the Mediterranean seagrass Posidonia oceanica. Aquat. Bot. 2005, 82, 269-283. [CrossRef]

28. Aragonés, L.; López, I.; Villacampa, Y.; Serra, J.C.; Saval, J.M. New Methodology for the Classification of Gravel Beaches: Adjusted on Alicante (Spain). J. Coast. Res. 2015, 31, 1023-1034. [CrossRef]

29. García-Andreu, C.; Saval, J.M.; Rojas, M.F.; Chinchón-Yepes, S. Caracterización de la cenizas de Posidonia oceánica para su utilización como material de construcción. Ing. Civ. 2008, 149, 131-140.

30. Saval, J.M.; Lapuente, R.; Navarro, V.; Tenza-Abril, A.J. Fire-resistance, physical, and mechanical characterization of particleboard containing Oceanic Posidonia waste. Mater. Constr. 2014, 64, e019. [CrossRef]

31. Maciá, A.; Baeza, F.J.; Saval, J.M.; Ivorra, S. Mechanical properties of boards made in biocomposites reinforced with wood and Posidonia oceanica fibers. Compos. Part B Eng. 2016, 104, 1-8. [CrossRef]

32. García-Andreu, C.; Sava, J.M.; Chinchón-Yepes, S. Análisis de las características físicas y mecánicas de morteros de cemento con adición de cenizas de Posidonia oceánica. Ing. Civ. 2008, 150, 89-101.

33. Saval Pérez, J.M. Estudio del Residuo de Posidonia Oceánica Utilizado Como Adiciones en Morteros de Cemento. Ph.D. Thesis, Universitat d'Alacant-Universidad de Alicante, Alicante, Spain, 2003.

34. Aguir, C.; M'Henni, M.F. Experimental study on carboxymethylation of cellulose extracted from Posidonia oceanica. J. Appl. Polym. Sci. 2005, 99, 1808-1816. [CrossRef]

35. Bettaieb, F.; Khiari, R.; Dufresne, A.; Mhenni, M.F.; Belgacem, M.N. Mechanical and thermal properties of Posidonia oceanica cellulose nanocrystal reinforced polymer. Carbohydr. Polym. 2015, 123, 99-104. [CrossRef] [PubMed]

36. Kok-Seng, C. Workability and Stability of Lightweight Aggregate Concrete from Rheology Perspective. Ph.D. Thesis, University of Singapore, Singapore, 2006. 
37. ACI Committee 238. Report on Measurements of Workability and Rheology of Fresh Concrete; ACI Committee: Farmington Hills, MI, USA, 2008; ISBN 9780870312687.

38. AENOR UNE-EN 1097-7. Ensayos para Determinar las Propiedades Mecánicas y Físicas de los áridos. Parte 7: Determinación de la Densidad Real del Filler. Método del Picnómetro; Normas UNE 2009; Spanish Association for Standardization: Madrid, Spain, 2009.

39. AENOR UNE-EN 450-1. Cenizas Volantes para Hormigón. Parte 1: Definiciones, Especificaciones y Criterios de Conformidad; Normas UNE 2013; Spanish Association for Standardization: Madrid, Spain, 2013.

40. Payá, J.; Monzó, J.; Borrachero, M.; Perris, E.; Amahjour, F. Thermogravimetric Methods for Determining Carbon Content in Fly Ashes. Cem. Concr. Res. 1998, 28, 675-686. [CrossRef]

41. Bates, S.; Zografi, G.; Engers, D.; Morris, K.; Crowley, K.; Newman, A. Analysis of amorphous and nanocrystalline solids from their X-Ray diffraction patterns. Pharm. Res. 2006, 23, 2333-2349. [CrossRef] [PubMed]

42. Ávalos-Rendón, T.L.; Chelala, E.A.P.; Mendoza Escobedo, C.J.; Figueroa, I.A.; Lara, V.H.; Palacios-Romero, L.M. Synthesis of belite cements at low temperature from silica fume and natural commercial zeolite. Mater. Sci. Eng. B 2018, 229, 79-85. [CrossRef]

43. Kemethmüller, S.; Roosen, A.; Goetz-Neunhoeffer, F.; Neubauer, J. Quantitative analysis of crystalline and amorphous phases in Glass-Ceramic composites like LTCC by the Rietveld method. J. Am. Ceram. Soc. 2006, 89, 2632-2637. [CrossRef]

44. AENOR UNE-EN 1097-3. Ensayos para Determinar las Propiedades Mecánicas y Físicas de los áridos. Parte 3: Determinación de la Densidad Aparente y la Porosidad; Normas UNE 1999; Spanish Association for Standardization: Madrid, Spain, 1999.

45. Fernández-Fanjul, A.; Tenza-Abril, A.J.; Baeza-Brotons, F. A new methodology for determining particle density and absorption of lightweight, normal-weight and heavy weight aggregates in aqueous medium. Constr. Build. Mater. 2017, 146, 630-643. [CrossRef]

46. AENOR UNE-EN 1097-6. Ensayos para Determinar las Propiedades Mecánicas y Físicas de los áridos. Parte 6: Determinación de la Densidad de Partículas y la Absorción de Agua; Normas UNE 2014; Spanish Association for Standardization: Madrid, Spain, 2014.

47. Fernández-Fanjul, A.; Tenza-Abril, A.J. Méthode FANJUL: Dosage pondéral des bétons légers et lourds. Dosage pondéral des bétons légers et lourds 2012, 5, 32-50.

48. Spanish Association for Standardization. AENOR UNE-EN 1015-3-Métodos de Ensayo para Morteros de Albañilería. Parte 3: Determinación de la Consistencia del Mortero Fresco (por la Mesa de Sacudidas); Spanish Association for Standardization: Madrid, Spain, 2000.

49. Spanish Association for Standardization. AENOR UNE-EN 1015-6-Métodos de Ensayo de los Morteros para Albañilería. Parte 6: Determinación de la Densidad Aparente del Mortero Fresco; Spanish Association for Standardization: Madrid, Spain, 1999.

50. AENOR UNE-EN 12350-2. Ensayos de Hormigón Fresco. Parte 2: Ensayo de Asentamiento; Spanish Association for Standardization: Madrid, Spain, 2009.

51. AENOR UNE-EN 12350-5. Ensayos de Hormigón Fresco. Parte 6: Determinación de la Densidad; Spanish Association for Standardization: Madrid, Spain, 2009.

52. Solak, A.M. El Fenómeno de la Segregación en Hormigones Ligeros. Análisis Mediante Procesamiento de Imágenes y Estudio Ultrasónico. Master's Thesis, Universidad de Alicante, Alicante, Spain, 2017.

53. Navarrete, I.; Lopez, M. Understanding the relationship between the segregation of concrete and coarse aggregate density and size. Constr. Build. Mater. 2017, 149, 741-748. [CrossRef]

54. Petrou, M.F.; Wan, B.; Gadala-Maria, F.; Kolli, V.G.; Harries, K.A. Influence of mortar rheology on aggregate settlement. ACI Struct. J. 2000, 97, 479-485.

55. Chen, H.-J.; Wu, K.-C.; Tang, C.-W.; Huang, C.-H.; Chen, H.-J.; Wu, K.-C.; Tang, C.-W.; Huang, C.-H. Engineering properties of self-consolidating lightweight aggregate concrete and its application in prestressed concrete members. Sustainability 2018, 10, 142. [CrossRef]

56. Evans, J.D. Straightforward Statistics for the Behavioral Sciences; Brooks/Cole Publishing Company: Forest Lodge Rd Pacific Grove, CA, USA, 1996; ISBN 0534231004; 9780534231002.

(C) 2018 by the authors. Licensee MDPI, Basel, Switzerland. This article is an open access article distributed under the terms and conditions of the Creative Commons Attribution (CC BY) license (http:/ / creativecommons.org/licenses/by/4.0/). 